\title{
SOBERANIA E REPRESENTAÇÃO: HOBBES, PARLAMENTARISTAS E LEVELLERS ${ }^{1}$
}

Eunice Ostrensky

Parece haver pouca dúvida de que entre 1642 e 1651 Thomas Hobbes alterou significativamente a estrutura de sua explicação sobre a soberania. Para chegar a essa constatação, basta passar os olhos pelos índices de Elements of law (1640) e De cive (1642) e perceber que essas obras não possuem uma passagem correspondente ao capítulo XVI do Leviatã (1651), notável por tratar da representação política. Mas se é evidente por si o caráter inovador da teoria da autorização no Leviatã, é menos fácil entender, em contrapartida, os motivos que teriam levado Hobbes a inovar. Minha intenção, neste artigo, é discutir alguns desses motivos.

Para certos intérpretes, preocupações exclusivas com a coesão interna do suposto sistema de política teriam levado Hobbes a notar importantes lacunas na sua teoria e, na tentativa de aprimorar as teses contratualistas, o filósofo acabaria por reformular as premissas desse

\footnotetext{
1 Leveller é o nome pejorativo - quase uma acusação - com o qual se designava certos políticos radicais na Inglaterra do século XVII. Os homens identificados como tais não tinham, porém, uma autodenominação própria.
} 
argumento $^{2}$. A pergunta que esses comentadores não se fazem é se não parece ingênuo supor que até então Hobbes não tivesse se dado conta de contradições tão flagrantes de sua teoria. Por sua vez, outros intérpretes julgam que adoção da linguagem da representação, de índole parlamentarista, e o consequente abandono da retórica ostensivamente realista não podem ser explicados pela análise interna das obras de Hobbes $^{3}$. Ou seja, não é possível entender por que o filósofo reformulou seus argumentos sem identificar os debates políticos nos quais ele teria se envolvido. Dessa perspectiva, a teoria política de Thomas Hobbes não se mostra como mero sistema de ideias, mas como intervenção em conflitos ideológicos de seu tempo.

Quentin Skinner, em especial, evidencia como Hobbes no capítulo XVI do Leviatã se apropriou do vocabulário originalmente posto em circulação pelos parlamentaris152 tas e escritores radicais da década de 1640 (Skinner, 2007, p. 159), não para endossá-lo, claro, mas para provar aos leitores que se poderia empregá-lo com resultados muito melhores numa teoria absolutista. Assim, teriam sido os críticos da monarquia de Carlos I os maiores responsáveis por colocar no centro do debate os termos autorização e representação, mais identificáveis ao papel dos representantes no Parlamento, como o próprio Hobbes reconhece no capítulo XIX do Leviatã com uma dose de amargura (Hobbes, 2003 [1651], p. 160). Quanto aos radicais, Skinner parece supor que a exploração das consequências mais subversivas desses conceitos manifesta uma continuidade com o vocabulário parlamentarista, agora empregado, ironicamente, contra seus primeiros expositores (Skinner, 2007, p. 167).

\footnotetext{
${ }^{2}$ Ver Gauthier (1969, p. 112); Zarka (1995, p. 198).

${ }^{3}$ Ver Wootton (1991, pp. 56-57); Skinner (2002a, p. 204; 2007).
} 
Pretendo complementar essa interpretação, adotando, pelo menos parcialmente, a hipótese de David Wotton, para quem "a teoria hobbesiana da autorização é um ponto de partida radical, cujo propósito é fazer frente aos levellers em seu próprio terreno" (Wootton, 1986, p. 57). Para isso, aponto pelo menos um aspecto importante de ruptura entre as doutrinas parlamentaristas e radicais: a defesa da soberania fundada no poder da multidão. De acordo com essa hipótese, os debates constitucionais que se seguiram à prisão de Carlos I e a eventual ascensão ao poder de grupos políticos hostis à ideia de soberania parlamentar significaram para Hobbes novos desafios teóricos, além dos já propostos pelos escritores parlamentaristas. Em face desse fato novo, Hobbes procurou, num só golpe, demolir as bem-sucedidas doutrinas parlamentaristas, que haviam se contraposto às pretensões absolutistas de Carlos I, e algumas doutrinas radicais, cujo propósito era pôr fim às pretensões absolutistas dos próprios parlamentaristas, principalmente os presbiterianos.

A Ordenação de Milícia, de 5 de março de 1642, marca o início da guerra civil que culminará com a prisão do rei, sua execução e a abolição da monarquia. Naquela data e por aquele instrumento, o Parlamento recrutava, em nome da majestade do monarca, um exército para conter a rebelião introduzida na Inglaterra pelos papistas e outras pessoas mal-intencionadas das quais Carlos I teria se cercado (Kenyon, 1993, p. 219). Aparentemente sem outra alternativa, o rei então se refugia em Oxford com suas próprias tropas. A partir daí, a soberania que antes radicava no rei, conforme reconhecem os próprios autores da Ordenação, transfere-se ao Parlamento, autodeclarado representante do reino, guardião da lei e, na ausência do rei, depositário da autoridade suprema. 
Esse gesto defensivo, porém ousado, encontra forte apoio entre vários panfletistas, sendo talvez o mais influente deles Henry Parker (Mendle, 1995, p. 2). Em Observations upon his Majesties late answer (1642), Parker retoma uma das teses centrais do protestantismo radical, formulada no século anterior por Du Plessis Mornay e George Buchanann, afirmando que o Parlamento cumpriu seu papel constitucional ao oferecer resistência aos desmandos de Carlos I. Na origem e de direito, o poder pertence ao povo, que o transmite ao rei sob a condição de exercê-lo para o bem do povo, não para seu uso próprio. Logo, todo poder político é fiduciário. Rompida a confiança elementar que deve unir o povo e o governante, o poder retorna ao detentor de direito (Parker, 1642, p. 16). Raciocínio semelhante se repete em outros escritos parlamentaristas divulgados entre 1642 e 1644. Em Fuller answer to a treatise by Doctor Ferne, de 1642, o teólogo presbiteriano Charles 154 Herle argumenta que os homens escolhem sua forma de governo e consentem quanto aos limites deste. Portanto, ao contrário do que defendem os partidários do direito divino dos reis, Carlos I deve prestar conta de seus atos aos súditos, dos quais emana toda autoridade secular. Também o autor de Touching the fundamentall lawes salienta que toda constituição, tendo origem humana, deve "ser regulada, corrigida e mantida pelo povo” (Anônimo, 1999 [1643], p. 278).

Ao lado desse argumento sobre a origem popular e os limites do poder político, esses autores parlamentaristas desenvolvem uma importante reflexão sobre o papel do Parlamento e sua relação com o povo. Se voltarmos às Observations, veremos Parker esclarecer que, violadas as condições do pacto, o poder supremo não retorna ao povo como multidão dispersa, mas somente ao povo como sociedade política organizada. Isso porque, embora seja o "livre e voluntário autor" do poder político (Parker, 1642, p. 1), 
o povo nem pode exercer diretamente o poder, sob pena de cair na mais profunda anarquia, nem transmiti-lo integralmente a um monarca, sob pena de experimentar a mais dolorosa tirania. É necessário criar um instrumento que impeça esses dois grandes inconvenientes, regulando o poder original mas turbulento do povo e controlando o poder derivado do monarca. Isso somente é possível graças à virtude da representação, que permite

a uns poucos agirem em nome de muitos, aos sábios consentirem pelos simplórios, de modo que a virtude de todos redunde em alguns e a prudência de alguns redunde em todos.

Instituída a representação por meio de eleições - a maior das virtudes que se pode conceder a um homem -, o Parlamento passa a ser, finalmente, "o verdadeiro corpo do povo". Assim, quando o rei trai a confiança que nele foi depositada no momento do contrato, o povo "assume o próprio poder de se fazer justiça sem causar distúrbios a si ou dano aos príncipes" (Parker, 1642, p. 15). Melhor dizendo, o povo que assume o poder nessas situações de violação do contrato é o Parlamento, o qual, na verdade, é o próprio Estado, por sua virtude de representar proporcional e geometricamente todos os ingleses (Parker, 1642, p. 28).

Em Fuller answer, Charles Herle adota uma explicação semelhante. Para ele, a relação do homem com o poder político não é de mera sujeição, é também de autoria (Herle, 1999 [1642], p. 253). Isso não significa, entretanto, que cada indivíduo reassuma o poder original quando violado o contrato. A resistência é legítima, não em nome da suposta crueldade sofrida pelo povo, mas dos princípios constitucionais subjacentes ao próprio governo: há uma reserva, no Parlamento, de poder de resistência em nome 
da preservação de todo o reino, do contrário o governo seria uma monarquia absoluta (Herle, 1999 [1642], p. 256). É preciso deixar claro, por outro lado, que só o Parlamento dispõe dessa reserva. O povo, detentor original do poder político, "não reservou nenhum poder em si, a não ser o que reservou para si no Parlamento" (Herle, 1999 [1642], p. 255). Herle está pressupondo que o povo alienou todo o seu poder de resistência ao Parlamento, de tal maneira que seria totalmente ilegítima uma ação do povo contra o Parlamento, no quase inimaginável caso de o Parlamento vir a empregar essa reserva contra o próprio povo. Não há, portanto, direito individual nem coletivo de resistência fora do Parlamento.

$\mathrm{O}$ autor de Touching the fundamentall lawes, embora concorde com o quadro geral descrito por Parker e Herle, apresenta algumas restrições a esta última afirmação; restrições, entretanto, que estão longe de ser claras: ora 156 o Parlamento parece ser a autoridade suprema no reino, ora o povo é a fonte última de legitimidade do poder. De acordo com o escritor anônimo, Deus exige a remoção dos tiranos de seus tronos e para essa tarefa convoca o povo, em quem se funda originalmente toda a autoridade, ou seus fideicomissários (Anônimo, 1999 [1643], p. 279), isto é, aqueles que expressam, em virtude da eleição, o conjunto de todos os homens. Quanto aos parlamentares, eles estão obrigados, por dever de consciência, a resistir à vontade arbitrária do rei. De fato, eles não apenas receberam, em confiança, a autoridade e o cargo para concentrar a autoridade universal e popular, como ainda, na qualidade de "atores representantes" (Anônimo, 1999 [1643], p. 279), supõe-se que atuem visando à ordem, ao bem público e à conservação. Nesse caso, nenhuma autoridade é superior à deles, nem mesmo a da lei. O autor anônimo parece presumir que a ação do povo fora do Parlamento tende a ser menos ordeira quando se resiste 
à vontade autoritária do governante e por isso sempre é mais recomendável que os fideicomissários ajam em seu nome. Mas, apesar disso, não se pode tirar do povo no seu conjunto, detentor por direito da autoridade, e de cada indivíduo em particular, toda possibilidade de resistência, senão os meios (a criação de instituições) contradiriam os fins (a preservação). Nesse sentido, se o próprio Parlamento viesse a praticar abusos e usurpações, para os quais não recebeu, nem poderia, autoridade, então estaria sujeito a sofrer resistência legítima por parte do povo (Anônimo, 1999 [1643], pp. 278-279).

Com sua maneira um pouco tortuosa de argumentar, o escritor anônimo expunha uma inconsistência dos discursos parlamentaristas: se a soberania radica no povo, quem reassume o poder em caso de resistência ao governante? Afirmar que é o Parlamento, na qualidade de corpo representante, pressupõe a celebração de um contrato entre o povo e seus representantes, por meio do qual o primeiro consente em alienar seu poder original aos últimos, nada mais retendo para si. É isso o que diz expressamente Herle em Fuller answer: "o Parlamento é o próprio consentimento do povo, o qual, uma vez empenhado, não é mais possível revogar" (Herle, 1999 [1642], p. 255). No entanto, não se poderia dizer igualmente, contra os parlamentaristas, que os homens consentiram em alienar seu poder ao rei e não mais tinham direito a retomá-lo? Salvo engano, essa é uma das linhas em que investe a argumentação de Hobbes em Elements of law e De cive. Seja como for, ao negarem a possibilidade de resistência ao povo, os parlamentaristas pareciam extrair conclusões muito próximas às dos realistas, os quais negavam todo direito de resistência aos súditos. Mas nessa quadra da década de 1640 muitos realistas viam, através da guerra civil instalada no país, como era estéril apostar apenas no discurso da não resistência. Por isso ficava fácil aos realistas vaticinar que dentro em pouco 
aquele a que se atribuía o poder original, o povo fora do Parlamento: reivindicaria a soberania pela resistência às ações ilegítimas do Parlamento.

Em 1645, John Lilburne, político leveller bastante reconhecido, tinha a clara percepção de que o Parlamento havia se tornado tão tirano como Carlos I. Não era à toa: Lilburne estava preso por ordem do Parlamento, apesar de seu engajamento, nos anos anteriores, na causa desse mesmo Parlamento contra o rei. Não cabe investigarmos aqui os motivos da prisão de Lilburne e da conversão do Parlamento em opressor. Basta sabermos que, desde 1642, o Parlamento jamais havia se preocupado em recusar a soberania ou mesmo dividi-la com a coalizão que combatera o rei. Agora, já não era mais possível ignorar que o absolutismo do Parlamento fazia suas vítimas, entre as quais Lilburne.

158 Se nos voltarmos para o principal argumento contra a soberania do Parlamento, veremos que se fundamentava no direito do povo ao autogoverno, de acordo com o qual nenhum homem jamais poderia consentir em alienar inteiramente seu poder a quem quer que fosse não importa se rei ou Parlamento. A razão é simples: seria insensato um contrato por meio do qual o detentor original do poder se comprometesse a sofrer dano quando o suposto fideicomissário julgasse conveniente. Um ser racional, portanto, não concede poderes ilimitados e arbitrários às instituições criadas para lhe proporcionar o bem. Todo pacto de alienação de poder, com compromisso de não resistência, é ipso facto nulo; só tem vigência o pacto de delegação de poder e apenas enquanto se mantiver a relação de confiança entre as partes contratantes. É isso o que diz Lilburne em um panfleto, redigido na prisão, na tentativa de lembrar aos seus ex-aliados, agora algozes, de que "o povo nunca seria tão tonto a ponto de conceder tamanho poder 
àqueles a quem escolhe como seus servidores" (Lilburne, 1998a [1645], p. 6) ${ }^{4}$.

Podemos pensar que até esse momento Lilburne ainda não conseguisse acreditar que "o povo" no qual ele próprio se incluía não era o mesmo "povo" do qual o Parlamento o excluía. Segundo uma visão tradicional, o povo que participa do Parlamento é o conjunto dos ingleses livres, isto é, homens cujos rendimentos atinjam 40 libras anuais $^{5}$. Esse é o prerrequisito básico para o exercício mais elementar e reduzido da cidadania. Abaixo desse limite, considera-se que os indivíduos não sejam livres por não terem uma vontade independente. Precisam, então, viver sob as ordens de outro e ser representados por aqueles a quem estão sujeitos; do contrário, não passam de mera multidão. O reino, por sua vez, é constituído por todo esse conjunto de pessoas, ou seja, tanto as que podem se apresentar pessoalmente como as que devem ser representadas no Parlamento. De qualquer maneira, por esses critérios sociais e econômicos, operários, pequenos agricultores e comerciantes, gente sem a posse definitiva da terra, todos os artífices (carpinteiros, alfaiates, pedreiros), enfim, homens que estavam sob as mesmas bandeiras de Lilburne, não eram livres, não eram cidadãos, não eram o povo, não tinham direitos. Se as instituições políticas - a monarquia, o Parlamento, os juízes e os vários tribunais - oprimiam-nos, é porque, conforme o modelo tradicional de autoridade, eles haviam nascido apenas para obedecer $^{6}$. Essa interdição se baseava num certo cálculo de

\footnotetext{
${ }^{4}$ Veja-se também Lilburne (1998b [1646], p. 317).

${ }^{5}$ O próprio Henry Ireton fornece esse número (apud Sharp, 1998, p. 104). Ver também Smith (1968 [1583]). Locke (2007 [1669]) endossa uma concepção semelhante de povo.

${ }^{6}$ Veja-se, mais uma vez, Smith (1993 [1566], p. 212): "Eles não têm nenhuma voz ou autoridade na nossa república e seu valor consiste em ser governados, não em governar outros, embora não possam ser inteiramente negligenciados".
} 
consequências. Se serviçais tivessem direito de agir como homens livres, participando ativamente como cidadãos, uma de duas consequências se seguiria: ou eles tenderiam a votar de acordo com as vontades de seus senhores, ou poderiam, votando de acordo com seus próprios interesses, propor medidas que resultassem na revisão ou até mesmo anulação da propriedade historicamente constituída, a qual ampara toda hierarquia política e social. Nada impediria que tais homens, dotados de poder político e autoridade suficiente para modificar as leis vigentes, propusessem e conseguissem no Parlamento a revogação do direito de propriedade e, em seguida, a distribuição das terras já demarcadas entre todos - ou pelo menos entre todos os que fossem julgados merecedores delas (Sharp, 1998, p. 114).

Essa concepção tradicional de autoridade, com todo o temor de uma revolta social que ela deseja suprimir, é 160 ostensivamente desafiada pelos levellers durante os Debates de Putney, em outubro de 1647. O que motiva esses debates é o Acordo do Povo, documento redigido pelas lideranças dos soldados com a finalidade de ser o contrato fundador de uma nova sociedade, criada pela renovação do Parlamento; uma declaração de direitos e, por isso, o esboço de uma constituição escrita. De todo o Acordo, o ponto que constitui o verdadeiro pomo de discórdia entre os representantes dos soldados e os oficiais do Exército, liderados por Oliver Cromwell e Henry Ireton, é a proposta de ampliação do colégio eleitoral que permitirá renovar o Parlamento e fundar uma nova sociedade. Conforme o diagnóstico dos soldados, cujos líderes são majoritariamente levellers, estariam excluídos do Parlamento homens com um genuíno interesse na continuação ou revisão do governo. Entretanto, esses homens deram provas de seu interesse quando, ao irem para a guerra, perderam seus trabalhos e seus parentes, além de arriscarem a própria vida em 
nome do país, como lembra o capitão Edward Sexby (apud Sharp, 1998, p. 120). É razoável que a vida, aquilo que Deus e a natureza concedem, seja um bem muito superior à propriedade imobiliária garantida por lei humana, mas de origem duvidosa, já que nem o diabo, lembra o coronel Rainborough, sabe por que alguns homens a têm e outros não (Sharp, 1998, p. 114). Para o exaltado coronel Rainborough, o "dom da razão", sem outra propriedade, deve ser suficiente para garantir a todos os homens adultos o direito de votar, ou seja, sua independência (apud Sharp, 1998, p. 109).

$\mathrm{Na}$ reforma social arquitetada pelos levellers, a redefinição dos critérios de representação permitiria substituir, como base de direitos políticos, o direito de propriedade pelo direito inato (Crawford, 2001, p. 200). A partir disso, a condição universal de ter nascido livre se converteria em critério de cidadania: o povo deixaria de ser constituído unicamente por aqueles que possuem, segundo Ireton, "um interesse permanente no país” (apud Sharp, 1998, p. 114) e passaria a incluir todos os indivíduos racionais que vivessem no país. A esse fenômeno de inclusão poderíamos chamar, retrospectivamente, de "processo de democratização do povo”. Seu pressuposto, como parece claro, é a defesa do igualitarismo que tanto assustava os críticos dos levellers na década de $1640^{7}$.

Mas esse movimento capaz de transformar o que antes era multidão dispersa em povo, embora já seja bastante, ainda não é suficiente para refrear opressão, enquanto o Parlamento puder permanecer alheio às demandas dos eleitores. A ampliação do colégio eleitoral exige, necessariamente, a reformulação dos mandatos dos representantes. Assim, mesmo aceitando que o Parlamento tenha o

${ }^{7}$ Um desses críticos é o presbiteriano Thomas Edwards, autor de Gangraena (Wootton, 1991, p. 417). 
poder de promulgar e revogar leis, criar e abolir cargos e tribunais, indicar e afastar magistrados, declarar a guerra e a paz, celebrar tratados com países estrangeiros etc., os levellers recusam-se a admitir que tais atribuições configurem a posse da soberania absoluta. Pelo contrário: a Quarta Cláusula do Acordo estabelece expressamente que "o poder destes e de todos os futuros representantes desta nação é inferior apenas ao daquele que os escolhem" (Sharp, 1998, p. 95). Como vimos, essa ideia constitui uma das pressuposições básicas dos levellers, traduzindo o caráter inalienável dos direitos dos representados, isto é, poderes que não são passíveis de representação e, caso desrespeitados, autorizam o povo a dissolver o Parlamento. Agora já é possível dizer que o povo fora do Parlamento, não representado, é o juiz de sua segurança. Por conta disso, as leis nunca poderiam ser nocivas à segurança e ao bemestar do povo sem se tornarem, ato contínuo, ilegítimas. 162 Daí, nas palavras de John Wildman, participante dos Debates de Putney, a máxima inegável de governo: "todo governo reside no livre consentimento do povo" (apud Sharp, 1998, p. 116).

É importante atentarmos para as implicações mais subversivas desses princípios. Em primeiro lugar, a afirmação da superioridade dos representados sobre os representantes leva ao paroxismo a máxima parlamentarista "o rei, embora seja singulis mayor, é universis minor" (Parker, 1642, p. 2) ${ }^{8}$. Para os parlamentaristas, o contrato que confere autoridade ao rei não o torna superior ao corpo do povo (em sentido estrito), o que deixa espaço para resistência quando o rei abusa de sua autoridade. Os levellers concordam com o teor dessa máxima e sua consequência. No entanto, eles ressalvam que o contrato não torna nenhum

\footnotetext{
${ }^{8}$ Para Hobbes, essa máxima é simplesmente absurda (Hobbes, 2003 [1651], p. 156); ver Skinner (2007, p. 164).
} 
representante superior ao corpo do povo (em sentido amplo). Se praticarem abusos, os representantes devem se sujeitar a sofrer a resistência dos representados, verdadeiros donos da soberania, porque sempre é necessário combater a arbitrariedade, onde quer que ela esteja, sob pena de se converter o homem livre em escravo, propriedade de outro. Além disso, agora se entende povo menos como a unidade reunida no Parlamento e mais como multidão de indivíduos dispersos cujos direitos naturais têm prioridade sobre todo o resto. Nesse sentido, os direitos coletivos da sociedade - os direitos civis - não se sobrepõem aos direitos individuais ou naturais. Em segundo lugar, o consentimento e a delegação de poder não parecem apenas estritamente condicionais, mas sobretudo contínuos (Wootton, 1986, p. 57). Dizer, como Rainborough, que os homens só estão obrigados às leis com as quais tenham consentido, ou, como William Petty, que "se houver uma constituição em que o povo não seja livre, essa constituição deve ser anulada”, equivale a atribuir o critério de legitimidade de uma instituição ao consentimento presente e contínuo de todos os cidadãos, e de cada um separadamente. Atos pretéritos de submissão não são, portanto, obrigatórios por eles mesmos. O consentimento é individual: cada um consente com os atos de autoridade, mas retira seu consentimento se vier a se julgar prejudicado em seus direitos e sua liberdade. Enfim, o que os levellers advogam é, ao mesmo tempo, o direito de voto e de revolta com base na dissolução da categoria política "povo" que amparava as pretensões absolutistas dos parlamentaristas.

Essa reivindicação não só não foi atendida, como rechaçada. Em 15 de novembro de 1647, um regimento de soldados atravessou o campo de Corkbush com o texto do Acordo pregado nos chapéus e aos gritos de "Liberdade da Inglaterra”, sinalizando sua subscrição a esse contrato social. Era o começo do fim da liberdade dos levellers. Um dos amotina- 
dos, escolhido por sorteio e para servir de exemplo, foi executado à frente de seu regimento (Le Claire, 2001, p. 33). A mensagem de Cromwell e dos oficiais era clara: o exército não se converteria numa populaça armada. Dois anos mais tarde, em 1649, a execução de Carlos I mostra não haver mais motivo para manter o exército mobilizado. A multidão perdia o poder.

Não há razão para supor que Thomas Hobbes fosse alheio ao debate - e ao combate - entre realistas, parlamentaristas e radicais que se desenrolava na Inglaterra em meados da década de 1640. Na sua autobiografia em versos, Hobbes conta que, quatro anos depois do início da guerra civil (em 1646), quando se exilam em Paris para fugir da fúria popular, o futuro Carlos II e sua corte, ocorreu-lhe a ideia de escrever um livro. Embora nesse momento o filósofo estivesse muito concentrado na redação do De corpore, ele 164 simplesmente não consegue aceitar que os adversários do rei atribuam seus êxitos a Deus. Diante disso, ele decide pôr de lado sua obra metafísica para escrever algo capaz de absolver as leis divinas. Mas o filósofo não contava que um período de doenças e dificuldades atrapalharia os dois projetos - aliás, mais o livro de metafísica que o de política. Só em 1649, com a saúde em ordem, Hobbes regressa à ciência civil graças a uma urgência: a execução do rei. Esse acontecimento trágico o faz sentir a necessidade de fornecer uma resposta rápida, coerente e persuasiva aos seus conterrâneos, que nesse meio tempo se achavam submetidos, continua o filósofo na autobiografia, a "uma malta rebelde", que governava "a frívola populaça sem lei". O teor dessa obra, que terá o "terrífico título de Leviatã" (Hobbes, 1994, p. 259), escandaliza alguns conhecidos a quem ela é divulgada, entre os quais Edward Hyde, futuro conde de Clarendon. Parece deliberada a intenção de chocar. Conversando com Hyde, Hobbes jocosamente lhe 
revela que publicará a obra porque tem "a intenção de voltar para casa" (Hyde, 1676, p. 3).

Meses depois, já expulso da corte exilada, Hobbes estará de volta à Inglaterra, deixando atrás de si um clero furioso e ressentido. Como Hyde prontamente percebeu, o Leviatã havia se distanciado da retórica realista e anglicana empregada em Elements of law e De cive. Agora Hobbes desejava contribuir para o debate constitucional do país, posicionando-se a favor das novas autoridades e contra os revoltosos da nova ordem - os radicais. Esse desejo está formulado na Epístola Dedicatória dessa obra, quando Hobbes afirma que seu discurso sobre a república se coloca entre dois extremos, entre os que "se batem, de um lado, por excessiva liberdade" e, de outro, "por excessiva autoridade" (Hobbes, 2003 [1651], p. 5). O que talvez Hyde não soubesse é que esse discurso não deveria ser tomado como apologia dos homens no poder, ou das pessoas naturais, e sim, como esclarece Hobbes na mesma Epístola, como defesa do poder civil, abstrato, isto é, das pessoas artificiais. O Leviatã trata da soberania, do Estado, e não da pessoa que representa a soberania - seja Carlos, Oliver ou John.

Quanto ao conteúdo da obra, já se sabe que uma das grandes inovações introduzidas por Hobbes, ao lado de toda a reformulação da parte relativa à religião, é o emprego do vocabulário da autorização na compreensão das chamadas "pessoas artificiais". Em Elements of law e De cive, apesar de Hobbes ter-se preocupado em definir onde reside a autoridade soberana (isto é, no corpo político), nunca considerou como ela vem a ser autorizada ou, noutras palavras, como ocorre a autorização. É no capítulo XVI do Leviatã que essa terminologia aparece pela primeira vez, na discussão dos requisitos à instituição da autoridade soberana. Como havia se proposto a fazer em toda a obra com o objetivo de constituir uma inédita ciência da 
política, também aqui Hobbes começa por definições, isto é, pelo significado dos termos "autor" e "ator", que seus oponentes parlamentaristas e levellers haviam empregado alguns anos antes. Para ele, quando estão em questão as pessoas artificiais, o "autor" é a pessoa a quem pertencem algumas palavras e ações, as quais são representadas, em certos casos, por um "ator" ou "representante". Nesse sentido, agir por autoridade - representar - é ter recebido um mandato ou licença para realizar uma ação da pessoa ou das pessoas que antes necessariamente possuíam o direito de praticar as ações elas mesmas. A partir dessa definição, a metáfora da "transferência de direito" adquire um novo significado, deixando de equivaler à mera renúncia indeterminada ao uso do direito para se tornar o ato de beneficiar outro com o uso desse direito. Com isso, a exemplo de seus adversários teóricos, Hobbes concorda que a via da democracia direta reserva inúmeros obstácu166 los - se bem que para os levellers esses obstáculos talvez não sejam intransponíveis, nem constituam um desestímulo para a realização das assembleias. Concorda também que a maneira mais conveniente de reduzir a multiplicidade de indivíduos a uma unidade é a representação, mecanismo mediante o qual uma pessoa natural recebe autorização para agir politicamente em nome de outras pessoas. Por último, aceita que só são legítimos os poderes autorizados. Poderes dos quais não sejamos autores, não são, portanto, obrigatórios: "ninguém está obrigado do qual não é autor, nem consequentemente por um pacto feito contra ou à margem da autoridade que ele mesmo conferiu" (Hobbes, 2003 [1651], p. 139).

Mas as convergências entre Hobbes e seus adversários teóricos se esgotam num plano básico da argumentação; nível suficiente, de qualquer maneira, para indicar como o primeiro se apropria do vocabulário dos últimos para extrair conclusões muito diferentes das que estes extraí- 
ram. A verdadeira finalidade de Hobbes é mostrar que a representação converte a multidão numa pessoa artificial, sim, mas numa pessoa artificial ao mesmo tempo independente das pessoas representadas e das pessoas representantes, distinta dos governantes e dos governados. Para isso, ele precisa argumentar que, contrariamente ao que supunham os parlamentaristas, não é o povo a origem do poder político, nem o detentor da soberania. É a multidão, conjunto desorganizado e heterogêneo de vontades, a origem desse poder, como defendiam os radicais. Porém, divergindo destes, Hobbes sustenta que a multidão é capaz de ação somente como unidade e, principalmente, que essa unidade mantém uma dependência visceral em relação ao poder coercitivo. Examinemos mais de perto o desenrolar dessa argumentação, começando pela crítica aos parlamentaristas.

De acordo com a principal doutrina dos parlamentaristas, o sujeito da soberania é o povo, categoria jurídica abstrata capaz de exercer uma vontade única e tomar decisões unificadas. Para Hobbes, essa tese repousa sobre um duplo, pernicioso e grosseiro erro que se faz necessário corrigir caso se queira, ao mesmo tempo, criar uma ciência política inspirada nos êxitos da geometria euclidiana e da física galileana, bem como evitar o prosseguimento da guerra civil. $\mathrm{O}$ primeiro erro Hobbes atribui, não sem maldade, à falta de estudo e entendimento dos parlamentaristas. Por precipitação, eles tomam o significado de "povo" por "multidão", ignorando que o primeiro termo indica a ação de muitos homens e o segundo, muitas ações de uma multidão. Daí a diferença de se dizer, por exemplo, que o senado romano matou Catilina e que muitos senadores mataram César (Hobbes, 2003 [1651], p. 89). Por conta dessa confusão inicial, incorre-se num segundo equívoco, ainda mais grave, o qual consiste em tomar o efeito pela causa, ignorando-se que a instituição do poder soberano exige a realização de 
um pacto entre indivíduos dispersos, e não entre o soberano representante e as partes (Hobbes, 2003 [1651], p. 150). Falar em povo soberano, em condições de pactuar e estabelecer restrições ao exercício da autoridade política, é pressupor um pacto prévio mediante o qual a multidão teria se organizado para adquirir uma vontade única. Ora, se há uma pessoa artificial única, essa pessoa só pode ser o representante, que unifica a vontade de muitos, nunca o representado. Quem representa só pode representar muitos; os representados, por sua vez, só constituem uma multiplicidade de vontades dispersas. Com alguma impaciência, é para essa trivialidade que Hobbes chama a atenção de seus leitores no capítulo XVI do Leviatã, carregando nas ênfases: "é a unidade do representante, e não a unidade do representado, que faz a pessoa ser una" (Hobbes, 2003 [1651], p. 141). Disso necessariamente resulta que apenas existe um povo depois, não antes, de instituída a soberania e criado 168 o Estado.

Revelados os erros sobre os quais se erige a (pseudo) categoria política conhecida como povo, cai por terra a base ideológica do pensamento parlamentarista, arrastando consigo duas importantes implicações constitucionais que se erguiam sobre essa base: a afirmação da soberania popular e a teoria do Parlamento como representante do povo. Se não existe povo antes do contrato, ou seja, um corpo unificado capaz de agir como vontade única, então é obviamente falsa a afirmação de que o povo impõe restrições à autoridade política do governante. Pela mesmíssima razão, tampouco é verdadeiro dizer que, violado o contrato do governante com o povo, a soberania é restituída ao povo. $\mathrm{Na}$ hipótese de rompimento do contrato, que constitui injustiça praticada pelos súditos, nunca pelo soberano (Hobbes, 2003 [1651], p. 152), o poder retorna à multidão e a soberania chega ao fim. Portanto, a expressão "povo soberano" é absurda, não quer dizer nada. 
Como consequência desse raciocínio, segue-se que também é falsa a teoria constitucional de acordo com a qual o Parlamento, como depositário da autoridade do povo e portanto como seu representante, detém a soberania. Decerto que os Parlamentos podem ser assembleias representativas, seja quando designam a associação civil criada pela multidão, seja quando se originam do poder soberano do Estado, com propósitos específicos. No primeiro caso, o Parlamento é portador da soberania absoluta na medida em que unifica, como representante, todas vontades múltiplas e dispersas da multidão (Hobbes, 2003 [1651], p. 160), não havendo nenhuma outra autoridade superior a sua ${ }^{9}$, no segundo caso, seu poder é limitado e subordinado ao representante absoluto (Hobbes, 2003 [1651], p. 191). O absurdo da teoria constitucional parlamentarista reside então na afirmação de que o povo pode ser representado, seja lá por quem for.

Essas considerações permitem a Skinner concluir que, ao criticar a tese da soberania popular, Hobbes estabelece uma importante distinção entre os poderes da soberania e os poderes do povo. O verdadeiro detentor da soberania não é nem o povo, como comunidade organizada, nem o rei (pessoa natural), mas uma pessoa jurídica e abstrata, conhecida como Estado, que, para agir, deve ser representado pelo soberano (Skinner, 2003, p. 66; 2002b, p. 394). Com efeito, o contrato enunciado no capítulo XVIII do Leviatã deixa claro que o representante da multidão é o Estado: "pessoa de cujos atos uma grande multidão, mediante pactos recíprocos uns com os outros, foi instituída por todas como autora" (Hobbes, 2003 [1651], p. 148). Essa pessoa, por sua vez, sendo fictícia ou artificial, deve

\footnotetext{
${ }^{9}$ O Parlamento já havia rejeitado, entretanto, tornar-se absoluto de direito, embora talvez já o fosse de fato. Conforme a Declaração de Março de 1649, "a permitirem os homens, esse oficial sem responsabilidade seria um estranho monstro" (Skinner, 2007, p. 175).
} 
ter como portador o soberano (Hobbes, 2003 [1651], p. 148). Parafraseando o poema "quadrilha" de Drummond, o soberano representa o Estado, que representa a multidão, que não representa ninguém, porque só pode ser representada.

De tudo quanto foi até agora exposto, talvez já se possa perceber que, visando os escritores parlamentaristas, o ataque de Hobbes atingia também as posições dos levellers, principalmente as relativas à soberania da multidão e a seu direito de resistência, o que desobrigava, em tese, o filósofo de empreender uma refutação específica de seus pressupostos. Mas os inúmeros leitores de Hobbes conseguiriam mesmo identificar nos argumentos acima um golpe certeiro nas pretensões dos levellers? Essa pergunta parece razoável em face da própria afirmação de Skinner, segundo a qual Hobbes estaria inteiramente convencido de que era possível desacreditar toda a teoria da autorização e da represen170 tação desenvolvida pelos parlamentaristas se sugerisse que não existe o corpo político do povo, ao contrário do que pretendia Henry Parker (Skinner, 2007, p. 163). Sem prejuízo disso, vimos que a metáfora do "corpo político" e suas ramificações não parecem exercer um papel dominante nos escritos levellers, talvez porque também eles se opusessem à ideia de que o povo só se organiza no Parlamento, sobretudo no Parlamento em que pensavam teóricos como Parker e Herle. Pelo contrário, se os panfletos levellers, apesar de sua falta de coesão e unidade, possuem uma característica comum, possivelmente ela se encontra na defesa dos direitos inalienáveis dos indivíduos. É o indivíduo, não a corporação política, que interessa aos levellers reivindicar. Disso resulta tanto sua concepção de atividade política baseada "na confiança no julgamento independente do homem comum" (Wootton, 1991, p. 433), como sua dificuldade de se constituir um grupo político organizado e até mesmo sua recusa em se conceber como organização partidária em 
competição pelo governo. Ainda segundo Wootton, "quando buscavam organizar motins militares, eles se mostravam previsivelmente desorganizados e despreparados" (1991, p. 425). Parece consequente com isso que os levellers não se apropriassem da metáfora do corpo político, não entendessem multidão como termo pejorativo e não reiterassem, afinal, todo o vocabulário parlamentarista.

No século XVII, deliberado ou não, o esforço de atribuir valor positivo à multidão encontrava obstáculos quase intransponíveis no temor e desprezo do povo. Era bastante comum ilustrar-se a multidão ou populaça pela metáfora da Hidra de Lerna, monstro de muitas cabeças. No segundo ato de Coriolano, de Shakespeare, os cidadãos temem receber a pecha infamante de multidão de muitas cabeças, pois isso implicaria a recusa a ouvir suas demandas. No Leviatã, Hobbes alerta que a Hidra, animada pela infinita ambição, opôs grandes dificuldades a Hércules: a cada cabeça que este lhe cortava, três outras surgiam no lugar (Hobbes, 2003 [1651], p. 295). Mas, mais do que a ambição popular, o que parece perturbar Hobbes nesse monstro era o mesmo que incomodava o Cardeal Retz. "A populaça é um monstro com muitas cabeças", dizia o Cardeal, "mas sem cabeça nenhuma e pouco cérebro. Toda assembleia numerosa é a populaça; tudo nela depende de inclinações instantâneas" (Edwards, 2008, p. 355). Símbolo da multiplicidade, inconstância, irracionalidade, licenciosidade, ignorância e balbúrdia, a multidão não deve ser contentada, sob pena de disseminação da desordem e da guerra civil.

É certo que o emprego do termo "multidão" não constitui uma inovação do Leviatã. Já em Elements of law, Hobbes definia corpo político como "multidão de homens, unidos como pessoa única por um poder comum, para sua paz, defesa e benefício" (Hobbes, 1994, p. 8) ${ }^{10}$. Não obstante,

\footnotetext{
${ }^{10}$ A este respeito, veja-se também Hobbes (1998 [1642]).
} 
o fato novo criado pela multidão em meados da década de 1640 está na ideia de que os indivíduos dispersos não apenas são os autores poder político, mas, principalmente, sua vontade e seu voto estabelecem as condições de legitimidade constante e inalienável desse poder. O consentimento só é válido enquanto for dado continuamente por todo indivíduo que compõe a multidão. Os atores, aqui, desempenham um papel secundário e inteiramente subserviente aos autores. É esse inegável lastro individualista da política, do qual a teoria de Hobbes sem dúvida partilhou desde o início, que agora parece ironicamente impor ao filósofo uma armadilha teórica: como evitar que se desfaça tão facilmente a relação de autorização que fundamenta o poder político?

Para esclarecer esse ponto, retornemos então aos conceitos de "autor" e "ator" formulados por Hobbes no capítulo XVI do Leviatã. Dizer que o ator representa o autor equi172 vale, para o filósofo, a dizer que o ator porta a pessoa do autor e atua em seu nome (Hobbes, 2003 [1651], p. 138). Disso se deduz que quem concede autoridade ao representante deve ser considerado autor de suas ações e assumir a responsabilidade por suas consequências (Hobbes, 2003 [1651], p. 138). Como resultado desse raciocínio, o filósofo em seguida infere que "quando o ator faz um pacto por autoridade compromete assim o autor, não menos do que se este mesmo o fizesse, nem o sujeita menos a todas as suas consequências" (Hobbes, 2003 [1651], p. 139). Portanto, de agora em diante, o teor do contrato que inaugura a sociedade civil não é mais de mera submissão ou renúncia voluntária ao uso do direito natural, mas de autorização: todas as ações do representante são ações do representados. Mais ainda, é importante - e surpreendente - notar que a partir daí o autor, não o ator, é quem adquire duas obrigações: primeira, ele deve assumir a responsabilidade pelas ações do representante feitas em seu nome; segunda, ele tem o 
dever de não interferir no cumprimento dessa ação quando realizada pelo representante (Skinner, 2002a, p. 184). Para ficarmos ainda nas metáforas, o autor deve reconhecer-se nas ações do ator e não pode entrar em cena enquanto a peça é encenada para corrigir, substituir ou suprimir o ator...

Essa análise permite notar que, embora aceite o vocabulário empregado por seus rivais, o filósofo formula, no capítulo XVIII do Leviatã, uma nova semântica para o termo representação ao inferir de seu significado um conjunto de obrigações dos representados perante os representantes, invertendo a fórmula política criada pelos levellers. Todos os atos e decisões do soberano representante pertencem aos representados e devem ser reconhecidos como atos e decisões deles (Hobbes, 2003 [1651], p. 149). Mesmo que os autores façam alegações chorosas de que não autorizaram determinadas ações ou de que havia um leque de limitações ao uso do direito original, o soberano argumentará com razão - e ele sempre terá razão - de que o mero fato de haver um soberano representante, não uma pessoa natural, indica que seus atos pertencem a outras pessoas, isto é, às que autorizaram sua existência: "aquele que se queixa de dano causado por seu soberano estará se queixando daquilo de que ele próprio é autor, portanto não deve acusar ninguém a não ser a si próprio" (Hobbes, 2003 [1651], p. 152). O mesmo vale para reivindicações de um suposto direito de resistência, fundado da ilusória quebra de contrato por parte do soberano, que - não custa lembrar - não pactuou com ninguém. Quem resistir por esse pretexto resistirá a sua própria vontade, a sua própria ação, coisa não menos irracional do que injusta, quer porque ninguém pode resistir a si mesmo, quer porque "constitui injustiça alguém praticar qualquer ato em razão do qual possa ser castigado pela própria autoridade" (Hobbes, 2003 [1651], p. 149). 
Além disso, essa pessoa artificial cuja alma é a soberania deve contar com o consentimento contínuo e universal da multidão, consentimento, portanto, sempre presente e irrevogável. Presente, na medida em que a multidão reconhece todos os atos do representante como seus, como se a vontade dos representados fosse constantemente reposta por toda ação do representante; irrevogável, porque não faz sentido dizer que o soberano rompe o contrato, já que ele não o celebrou. Enfim, é preciso criar, mais do que o consentimento, uma verdadeira unidade (Hobbes, 2003 [1651], p. 147). Não fosse assim, seria a guerra civil: o pavoroso retorno à condição pré-política e social que caracteriza o estado natural. Por outro lado, se a multidão conseguisse manter-se dispersa sem provar o veneno da própria inconstância e volubilidade, sem cair em guerra civil, "sem um poder comum que mantivesse a todos em respeito" (Hobbes, 2003 [1651], p. 145), então em nenhum lugar o Estado 174 teria sido criado, porque se atingiria paz sem coerção. Isso, porém, não existe. O que é então o grande Leviatã, senão o monstro capaz de dominar a multidão de muitas cabeças e assim lhe dotar de ação efetiva? Melhor ainda, o que é o terrífico Leviatã, que se levanta por trás dos vales e montanhas, senão o monstro de muitas cabeças em versão pacífica, ordeira e racional?

A lembrança da capa do Leviatã nos apresenta o derradeiro indício do empenho de Hobbes em convencer seus leitores de que o Leviatã é a multidão irremediavelmente unida num só corpo. De acordo com Keith Brown, o livro teria por capa um desenho, não a gravura que por razões incertas acabou recebendo e que muitas vezes serve de imagem simbólica não apenas do Estado coercitivo, como da própria ciência política, a qual nasce, a bem dizer, junto com a concepção moderna de Estado. O desenho foi parar na capa do exemplar com que o filósofo presenteou o rei Carlos II (Brown, 1978, p. 26). Entre as várias outras dife- 
renças entre a gravura e o desenho, uma delas, em especial, chama nossa atenção: o corpo do Leviatã. Na famosa gravura, o corpo é composto por outros tantos homens, mulheres e até mesmo crianças, que, com olhos apenas para o soberano, nos dão as costas; no desenho, há milhares de cabeças mirando o leitor. Mais curioso ainda é que o filósofo parece ter se envolvido diretamente na escolha deste desenho e na composição de seus elaborados detalhes. Sua intenção, segundo Noel Malcolm num artigo revelador, era não apenas sugerir uma perfeita correspondência entre o conteúdo do texto (a ideia de que o soberano porta coletivamente os súditos), como ainda alcançar um efeito virtual, criado com base num complexo aparato ótico inventado no final da década de 1620 (Malcolm, 1998, p. 201). Esse efeito, esclarece Malcolm, consistia em esvaziar o sentido tradicional de certo fenômeno para dotá-lo de um significado próprio, inteiramente novo, artificial e simbólico. Assim, no desenho de capa do Leviatã, Hobbes pretendia ao mesmo tempo desmistificar o poder soberano, assinalando no seu aspecto humano o fato de ser produto de uma escolha racional dos indivíduos, e investi-lo de um poder tão grande e terrífico que seria muito superior à soma do poder de todos os homens em seu interior (Malcolm, 1998, p. 228). As cabeças só seriam vistas em perspectiva - efeito semelhante ao visado por Holbein com a caveira no quadro "Os Embaixadores" -, exibindo, conforme o ângulo de visão, uma relação muito peculiar entre a multiplicidade e a unidade, e refletindo, desse modo, uma nova concepção do corpo político. Infelizmente para Hobbes, esse experimento ótico se mostrou uma impossibilidade física (Malcolm, 1998, p. 225).

Mas, embora mal-sucedido como experimento científico, o Leviatã tem pelo menos o mérito de indicar, nas suas imperfeições, que o monstro de muitas cabeças havia sido domesticado. Contra a ideia do consentimento individual, 
universal e constante defendida pelos levellers, Hobbes sustentava - no plano dos argumentos e das imagens - que, uma vez criada a república, já não era mais possível retirar o consentimento ou a procuração conferida ao soberano, mesmo nas inevitáveis situações de descontentamento. Isso porque, com a autorização, o consentimento inicial, o pacto fundador, se converteria em consentimento contínuo, em pacto incessante e tacitamente celebrado. Incorporando a multidão, o Leviatã pacifica e controla a turba revoltosa. É dessa maneira que se oferece como contraponto à instabilidade criada pela democracia radical. Ou era isso ou era a guerra de todos contra todos.

\section{$* * *$}

A finalidade deste artigo foi discutir como nos capítulos do Leviatã relativos à soberania Hobbes responde simul-

176 taneamente a dois grupos de adversários políticos distintos, desarticulando, de um lado, o conceito de povo e, de outro, desmistificando o indivíduo que se apresenta como sujeito de direitos inalienáveis. A resposta do filósofo tem, portanto, mão dupla: parte de sua crítica aos parlamentaristas estende-se aos levellers e, em contrapartida, parte do ataque aos levellers põe em xeque posições parlamentaristas subsidiárias das teses que examinamos. Além disso, ao escapar da alternativa populista, Hobbes não endossa, como se poderia pensar, o discurso realista. Essa talvez seja a mostra mais flagrante de sua habilidade em acomodar discursos adversários aos interesses de sua filosofia e transformá-los no inverso do que se pretendia; neste caso, numa versão modificada de duas teorias subversivas. Do ponto de vista da eficácia política, essa estratégia teórica soa temerária - afinal, talvez resultasse difícil aos leitores distinguir nitidamente a teoria de Hobbes da de seus rivais. Do ponto de vista da análise contemporânea, entre- 
tanto, a recomposição dessa estratégia nos permite avaliar como a teoria política de Hobbes, longe refletir a sabedoria de quem se encerraria numa torre de marfim para um diálogo atemporal com os pares, tem o propósito de interferir num debate tormentoso. Se as vozes dos outros participantes desse debate tendem a chegar até nós abafadas e quase inaudíveis, isso não implica que Hobbes não as tenha ouvido ${ }^{11}$.

\section{Eunice Ostrensky}

é professora do departamento de Ciência Política da FFLCH/ USP.

\section{Referências bibliográficas}

ANÔNIMO. 1999 [1643]. "Touching the fundamentall lawes". In: MAL-

COLM, J. L. (org.), The struggle for sovereignty: Seventeenth-Century English political tracts. Vol. 1. Indianapolis: Liberty Fund.

BROWN, K. 1978. "The artist of the Leviathan title-page". British Library Journal, vol. IV, no 2, pp. 24-36.

CRAWFORD, P. 2001. "The poorest she: women and citizenship in early modern England”. In: MENDLE, M. (org.). The putney debates of 1647: the army, the levellers, and the English State. Cambridge: Cambridge University Press.

EDWARDS, Tryon. 2008. A dictionary of thoughts. New York: Edwards Press.

GAUTHIER, David. 1969. The logic of Leviathan: the moral and political theory of Thomas Hobbes. Oxford: Claredon Press.

HERLE, C. 1999 [1642]. Fuller answer to a treatise by Doctor Ferne. In: MAL-

COLM, J. L. (org.). The struggle for sovereignty: Seventeenth-Century English political tracts. Vol 1. Indianapolis: Liberty Fund.

HOBBES, T. 1994 [1640]. Elements of law, natural and politic, with Three lives. Oxford: Oxford University Press. . 2003 [1651]. Leviatã. São Paulo: Martins Fontes. 1998 [1642]. On the citizen. Cambridge: Cambridge University Press.

KENYON, J. P. 1993. The Stuart constitution, 1603-1688: documents and commentary. Cambridge: Cambridge University Press.

\footnotetext{
11 "Nem mesmo as mais abstratas obras de política pairam acima da batalha: elas sempre são parte da batalha” (Skinner, 2008, p. XVI).
} 
LE CLAIRE, L. 2001. "The survival of the manuscript". In: MENDLE, M. (org.). The Putney debates of 1647: the army, the levellers, and the English State. Cambridge: Cambridge University Press.

LILBURNE J. 1998a [1645]. "On the $150^{\text {th }}$ page: an untitled broadsheet of August 1645”. In: WOODHOUSE, A. S. P. (org.). Puritanism and liberty: being the Army debates (1647-9) from the Clark manuscripts with suplementary documents. Chicago: Chicago University Press. . 1998b [1646]. "Postscrip to the free-man's freedom vindicated". In: WOODHOUSE, A. S. P. (org.). Puritanism and liberty: being the Army debates (1647-9) from the Clark manuscripts with suplementary documents. Chicago: Chicago University Press.

LOCKE, J. 2007 [1669]. “As constituições fundamentais da Carolina”. In: Escritos políticos. São Paulo: Martins Fontes.

MALCOLM, N. 2002. "The title page of Leviathan, seen in a curious perspective”. In: Aspects of Hobbes. Oxford: Oxford University Press, pp. 200-233.

MENDLE, M. 1995. Henry Parker and the English Civil War: the political thought of the public's "privado". Cambridge: Cambridge University Press.

SHARP, A. (org.). 1998. The English levellers. Cambridge: Cambridge University Press.

SKINNER, Q. 2002a. "Hobbes and the purely artificial person of the state”. In: Visions of politics, vol. 3. Cambridge: Cambridge University Press, pp. 177-208.

. 2002b. "From the state of princes to the person of the state". In:

Visions of politics, vol. 2. Cambridge: Cambridge University Press.

. 2003. El nascimiento del Estado. Buenos Aires: Editorial Gorla.

2007. "Hobbes on persons, authors and representatives". In: The

Cambridge companion to Hobbes's Leviathan. Cambridge: Cambridge University Press, pp. 157-180.

2008. Hobbes and republican liberty. Cambridge: Cambridge University Press.

SMITH, T. 1968 [1583]. "De Republica Anglorum”. In: DUNHAM, W. H.; PARGELLIS, S. Complaint and reform in England. Nova York: Octagon Books.

WOODHOUSE, A. S. P. (org.). 1975. Puritanism and liberty: being the Army debates (1647-9) from the Clark manuscripts with suplementary documents. Chicago: Chicago University Press.

WOOTTON, D. (org.). 1986. Divine right and democracy. London: Penguin Books. 
1994. "Leveller democracy and the Puritan Revolution". In: BURNS, J. H.; GOLDIE, M. (orgs.). The Cambridge history of political thought. Cambridge: Cambridge University Press, pp. 412-442.

ZARKA, Y. C. 1995. Hobbes et la pensée politique moderne. Paris: PUF.

\section{Outros materiais}

HYDE, E. 1676. A survey of Mr Hobbes his Leviathan. <http:/ / socserv.mcmaster.ca/econ/ugcm/3113/hobbes/clarend>. Acesso em: 22 jul. 2010.

PARKER, H. 1642. Observations upon some of His Majesties late answers and expresses. Original consultado na Biblioteca Britânica. 


\section{SOBERANIA E REPRESENTAÇÃO: HOBBES, PARLAMENTARISTAS E LEVELLERS}

\section{EUNICE OSTRENSKY}

$\mathrm{O}$ artigo pretende mostrar que Thomas Hobbes (1588-

210 1679) empregou o conceito de autorização política com o propósito de neutralizar discursos de dois grupos políticos adversários, os quais consideravam a representação um meio eficaz de responsabilizar atores políticos perante seus representados. Entre esses adversários, ocupam lugar de destaque os levellers, por terem proposto, em finais da década de 1640, uma saída constitucional inédita para o problema da ilegitimidade do Parlamento inglês: ampliação do sufrágio seguida da celebração do Acordo do Povo.

Palavras-chave: Soberania; Representação; Povo, Estado, Multidão.

\section{SOVEREIGNTY AND REPRESENTATION: HOBBES, PARLIAMENTARIANS AND LEVELLERS}

The article intends to show that Thomas Hobbes (1588-1679) adopted the concept of political authorization as means to fight against the doctrine of the accountability of political actors ahead 
of the persons they represented. Among these opponents, the levellers have a prominent place, by proposing, in the late 1640s, an innovative solution for the constitutional problem of the illegitimacy of the English Parliament: extension of the franchise followed by a celebration of an Agreement of the People.

Keywords: Sovereignty; Representation; People; State; Crowd. 